\title{
ANALISIS ENERGI TERSELAMATKAN PADA PDKB PT. PLN (PERSERO) JAWA BARAT BANDUNG
}

\author{
Mochamad Aji Gema Pribaya ${ }^{1}$, Ivany Sarief ${ }^{2}$ \\ 1,2Program Studi Teknik Informatika, Universitas Sangga Buana \\ ${ }^{1}$ korespondensi : mochajigp18@gmail.com ${ }^{1}$
}

\begin{abstract}
Work in Voltage Conditions (PDKB) is work that includes repair, maintenance, and network expansion, carried out under voltage or without turning off the operating network. The continuity of the supply of electrical energy is maintained so that customers do not have to worry about experiencing blackouts during the work. Saved energy is electrical energy that can still be delivered when work is carried out without blackouts. SUTM (medium voltage overhead line) is an electric power network that can be avoided from interference caused by several factors. This disturbance causes losses on the part of PT. PLN (Persero) as the electricity provider and the customer as the consumer's electrical energy. SUTM disturbance data in the work area of PT. PLN (Persero) West Java Bandung will be used in this research for June 2020. The results can be used as a reference for PLN officials so that SUTM can be more thorough and efficient.
\end{abstract}

Keywords: PDKB, Saved Energy, Saved Rupiah

\begin{abstract}
ABSTRAK
Pekerjaan Dalam Keadaan Bertegangan (PDKB) adalah pekerjaan yang meliputi perbaikan, pemeliharaan, dan perluasan jaringan, dilakukan dalam bertegangan atau tanpa memadamkan jaringan yang beroperasi. Kelangsungan suplai energi listrik tetap terjaga dengan demikian, pelanggan tidak perlu cemas mengalami pemadaman selama pekerjaan tersebut. Energi terselamatkan adalah listrik energi yang masih dapat tersalur saat pekerjaan dilakukan tanpa pemadaman. SUTM (saluran udara tegangan menengah) adalah jaringan tenaga listrik yang dapat dihindarkan dari gangguan yang disebabkan oleh beberapa faktor. Gangguan ini menyebabkan kerugian dari pihak PT. PLN (Persero) sebagai tenaga listrik penyedia dan pelanggan sebagai energi listrik konsumen. Data gangguan SUTM di wilayah kerja PT. PLN (Persero) Jawa Barat Bandung akan dimanfaatkan dalam penelitian ini untuk bulan Juni 2020. Hasilnya, dapat dijadikan acuan bagi pejabat PLN agar SUTM dapat lebih teliti dan efisien.
\end{abstract}

Kata kunci : PDKB, Energi Terselamatkan, Rupiah Terselamatkan

\section{PENDAHULUAN}

Listrik selalu menjadi polemik yang berkepanjangan di berbagai aspek kehidupan antara lain keuangan, ekonomi, sosial, budaya, politik, dan lain-lain. Situasi ini menandakan bahwa listrik mempunyai pengaruh yang sangat besar untuk kebutuhan masyarakat. Bukan tidak mungkin bahwa di masa yang akan datang keperluan listrik akan bertambah, itu disebabkan karena bertambahnya jumlah umat manusia dan juga akan muncul industri- industri baru yang jumlahnya tidak sedikit. Pemakaian jasa listrik merupakan hal utama yang sangat penting dalam kebutuhan umat manusia, baik itu untuk perkantoran, perusahaan, pabrik, kawasan industri dan yang lainya. Mengukur seberapa jauh keandalan pada sistem distribusi listrik yaitu sampai sejauh mana sistem distribusi listrik tersebut mengalami (gangguan), berapa lama waktu gangguanya dan berapa waktu yang dibutuhkan agar kondisi bisa kembali stabil.

Perludiketahui bahwa sistem yang memiliki jaminan yang tinggi dapat memberikan energi listrik ketika diperlukan, 
sementara sistem dapat dikatakan memiliki tingkat jaminan keandalan yang rendah jika ketersediaan energi listrik sangat minim.Maka dari itu keandalan sistem yang dapat menyalurkan energi listrik pada konsumen akan dipengaruhi oleh frekuensi padam penyulang. Karena Energi yang diproduksi tidak bisa tersalurkan, teknik pekerjaan dalam keadaan padam tersebut sangat merugikan konsumen dan kerugian perusahaan.

Dasar Hukum Pekerjaan Dalam Keadaan Bertegangan adalah Peraturan Menteri Energi dan Sumber Daya Mineral No: 001 Tahun 2005 yang berbunyi "Dalam upaya peningkatan pelayanan dengan mengurangi pemadaman listrik maka pekerjaan pemeliharaan dan perluasan TR s/d TET dapat dilaksanakan dalam keadaan bertegangan. di PT. PLN (Persero) Jawa Barat Bandung, pemeliharaan, perbaikan, dan perluasan penyulang menggunakan teknik Pekerjaan Dalam Keadaan Bertegangan (PDKB) dengan dapat menyelamatkan energi terbuang $(\mathrm{kWh})$ yang dapat menyelamatkan energi terbuang $(\mathrm{kWh})$ dan meningkatkan keandalan penyaluran listrik ke konsumen, yang meliputi 15 Gardu Induk (GI) dan 33 penyulang, sehingga layak untuk dilakukan dan ditingkatkan.

\section{TINJAUAN PUSTAKA}

Pekerjaan Dalam Keadaan Bertegangan (PDKB)

Pekerjaan Dalam Keadaan Bertegangan (PDKB) adalah pekerjaan yang dimana didalamnya terdapat perbaikan, pemeliharaan, dan semua itu dilakukan ketika kondisi bertegangan atau tanpa memadamkan jaringan yang saat sedang beroperasi. Keuntungan yang dapat diberikan oleh PDKB dilihatdari sisi pekerjaan ataupun dari sisi penjualan energi listrik ke konsumen, yaitu sebagai berikut :

1. PDKB dapat ditunda pekerjaan jika tidak selesai dalam 1 hari dan dapat diselesaikan pada esok harinya karena listrik tidak padam.

2. PDKB memiliki peralatan yang lengkap dan aman.

3. Dari sisi penjualan energi listrik, karena tegangan tidak padam maka enegi yang disalurkan akan maksimum dan menghasilkan keuntungan secara finansialperusahaan [1].

\section{Persyaratan PDKB}

Syarat umum untuk Pekerjaan Dalam Keadaan Bertegangan (PDKB) harus berdasarkan [2]. yaitu sebagai berikut :

1. Harus Ada Linemen

2. Harus Ada Groundmen

3. Harus Ada Pengawas K3, dan Pengawas Pekerjaan

4. Tanda tangan SP2B (Surat Perintah melaksanakan Pekerjaan Bertegangan) untuk Linesmen dan groundmen.

5. Tanda tangan SP3B (Surat Perintah Pengawas Pekerjaan Bertegangan)

6. Alat pelindung diri dalam keadaan baik yang dicek oleh pengawas K3 sebelumbekerja. 
Metode PDKB

Metode pelaksanaan Perkerjaan Dalam

Keadaan Bertegangan (PDKB) dibagi menjadi :

1. Metoda menggunakan Sarung Tangan Karet (Rubber Glove Method), biasanya untuk jaringan Tegangan Rendah (misalnya 480 Volts-1500 Volts).

2. Metoda menggunakan Tongkat Isolasi (Hot Stick atau Distance Method), biasanya untuk jaringan dengan Tegangan Menengah dan Tegangan Tinggi (misalnyajaringan bertegangan $20 \mathrm{kV} / 150 \mathrm{kV}$ ).

3. Metode dengan menyentuh langsung (Bare Hand Method).Biasanya untuk saluran udara tegangan Extra Tinggi (SUTET) dan Ultra Tinggi (misalnya jaringan dengan tegangan $230 \mathrm{kv}-500$ $\mathrm{kv})$.

\section{Keandalan Sistem Tenaga Listrik}

Keandalan merupakan tingkat kinerja suatu sistem atau bagian dari sistem, untuk mendapatkan hasil yang lebih baik pada periode waktu tertentu. Untuk dapat menentukan tingkat keandalan dari suatu sistem, harus diadakan pemeriksaaan dengan cara melalui perhitungan maupun Keandalan tenaga listrik adalah menjaga kontinuitas penyaluran tenaga listrik kepada pelanggan terutama pelanggan daya besar yang membutuhkan kontinuitas penyaluran tenaga listrik secara mutlak. Tingkat kontinuitas pelayanan dari sarana penyalur disusun berdasarkan lamanya upaya menghidupkan kembali suplai setelah mengalami gangguan [3].

\section{Ruang Lingkup Dan Batasan Masalah}

Dalam penelitian ini, terdapat ruang lingkup dan batasan masalah, yaitu :

1. Data-data Jumlah Energi yang Terselamatkan dan dengan adanya PDKB Tegangan Menengah pada bulan Juni 2020 di PT. PLN (Persero)Jawa Barat Bandung.

2. Rupiah data terselamatkan oleh PDKB Tegangan Menengah pada bulan Juni 2020.

3. Penelitian ini membahas sumber gangguan pada SUTM.

\section{METODE PENELITIAN}

\section{Diagram Alir ( Flow Chart) Penilitian}

Metodologi penelitian adalah proses langkah-langkah awal yang bertujuan agar penelitian dapat dilakukan dengan sistematis. Penelitian dilakukandengan berdasarkan tahapan awal hingga akhir yang dibuat dalam diagram alir. 


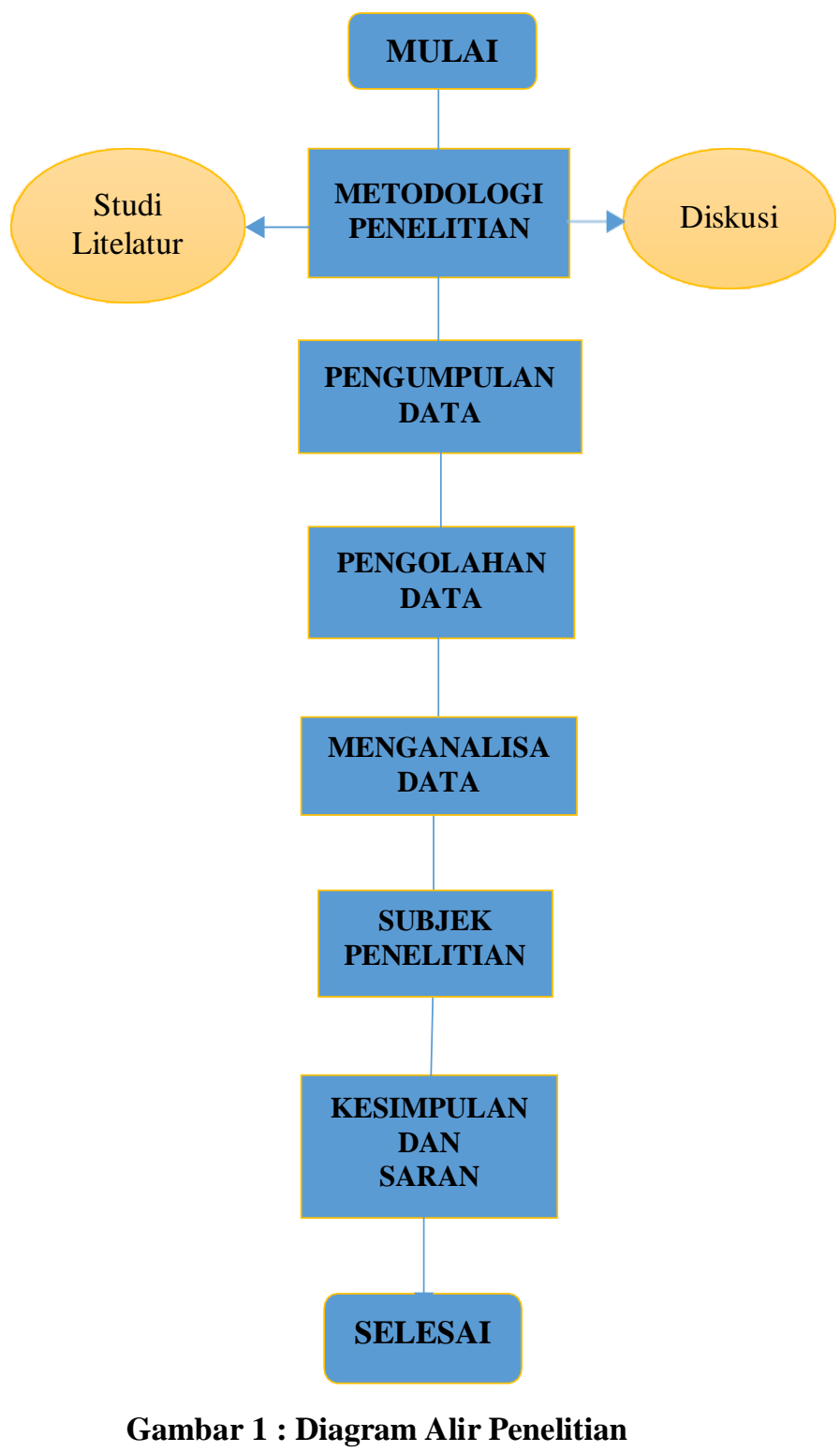

\section{Metode Metodologi Penelitian}

Pembahasan "Analisis Energi Terselamatkan Pada PDKB di PT PLN (Persero) Jawa Barat Bandung" dilakukan untuk menentukan faktor gangguan apa yang memiliki dampak yang lebih besar. Hasilnya, dapat digunakan sebagai acuan oleh PT. PLN (Persero) Jawa Barat Bandung untuk SUTM yang lebih efisien. Data hasil laporan Energi Terselamatkan dan Rupiah Terselamatkan merupakan penelitian dan pengumpulan datadata yang dikumpulkan. SUTM (Saluran
Udara Tegangan Menengah) yang sudah terjadi selama 1 bulan, yaitu Juni 2020 .

\section{Pengolahan Data}

Energi (Kwh) Terselamatkan

Energi $\mathrm{kWh}$ terselamatkan adalah energi listrik yang masih dapat tersalurkan saat dilakukan pekerjaan tanpa dilakukan pemadaman. Sedangkan energi tak terselamatkan adalah energi yang hilang akibat pemadaman untuk pekerjaan pemeliharaan, perbaikan, dan perluasan 
jaringan. Pada sistem 3 fasa, formulasi perhitungan energi terselamatkan dalam kilo Watt hour (kWh) [4]. adalah :

Esafe $=\underline{\sqrt{3} \times \mathrm{V}_{\mathrm{L}} \times \mathrm{I}_{\mathrm{L}} \times \cos \phi \times \mathrm{t}}$

$$
1000
$$

Keterangan :

$$
\begin{array}{ll}
\text { Esafe } & =\text { Energi terselamatkan }(\mathrm{kWh}) \\
\mathrm{V}_{\mathrm{L}} & =\text { Tegangan line to line }(\text { volt }) \\
\mathrm{I}_{\mathrm{L}} & =\text { Arus saluran (ampere) } \\
\cos \Phi & =\text { Faktor daya } \\
\mathrm{t} & =\text { Waktu pengerjaan (jam) }
\end{array}
$$

Setelah berhasil menghitung $\mathrm{kWh}$, berapa nilai rupiah yang dikalikan dengan harga rupiah per kWh yang sudah dipengaruhi oleh nilai tukar dollar, dan berapa nilai rupiah yang dikalikan dengan harga rupiah per $\mathrm{kWh}$ yang sudah dipengaruhi [5].

\section{Rupiah Terselamatkan}

Rupiah terselamatkan adalah hasil kesimpulan dari perhitungan Energi terselmatkan dengan harga perkWh / Bulan. Sehingga mendapatkan keuntungan yang berupa Rupiah, Dengan Rumus :

$\mathrm{Rp}=$ Esafe $\mathrm{x}$ perkWh / bulan

(2)

Dimana :

$\mathrm{Rp}=$ Rupiah

perkWh / Bulan = Rp.1206,40/kWh

\section{Subjek Penelitian}

Data yang diambil adalah Laporan bulanan yang dilakukan oleh Pekerjaan dalam Keadaan Bertegangan (PDKB). Dalam penelitian ini, yang dianalisa Identifikasi faktor-faktor yang berkontribusi terhadap terjadinya gangguan di SUTM. dan akibat yang ditimbulkan oleh gangguan SUTM yaitu :

\section{Penyebab Faktor gangguan SUTM JTM Components}

Gangguan adanya kerusakan pada listrik bahan-bahan yang digunakan pada jaringan tegangan menengah, seperti kawat penghantar, Fuse cut out, arrester, isolator, dan lainnya.

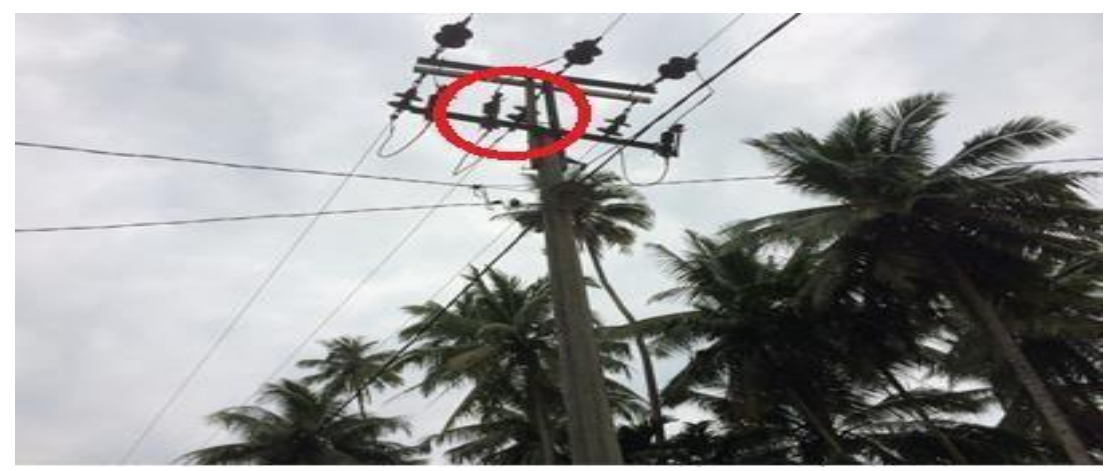

Gambar 2 : Contoh gangguan yang disebabkan komponen JTM

Gardu Tiang

Gangguan disebabkan oleh adanya kerusakan pada komponen gardu seperti trafo, obstijk kabel, NH Fuse, dan lain-lain. 


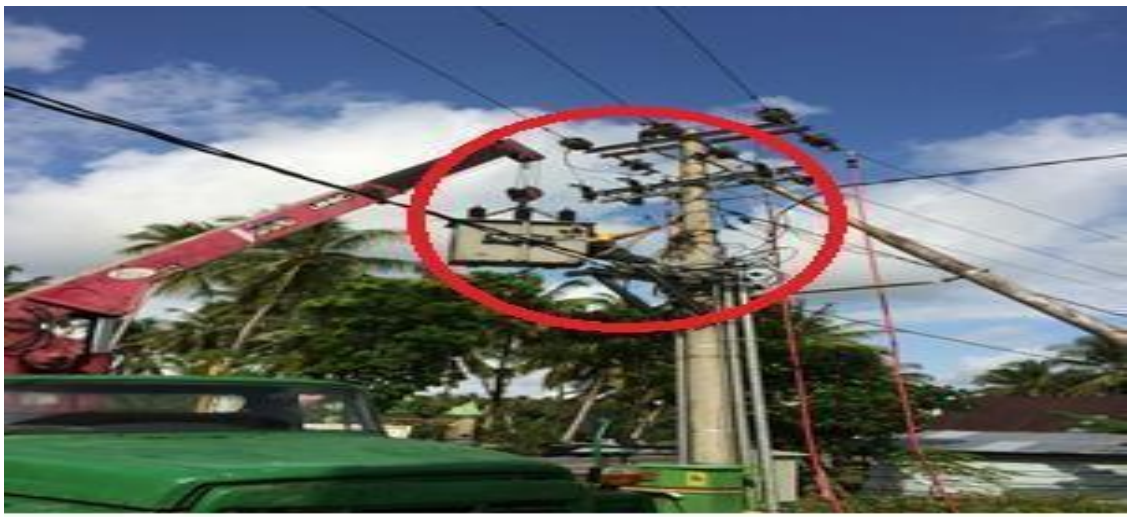

Gambar 3 : Contoh gangguan yang disebabkan oleh gardu

\section{Pohon}

Gangguan yang disebabkan oleh adanya bagian dari pohon yang mengenai jaringan SUTM, dengan mengakkibatkan terjadinya hubung singkat antar fasa pada penghantar SUTM. Sehingga dapat menimbulkan gangguan yang dapat berakibat padamnya aliran listrik pada jaringan tersebut.

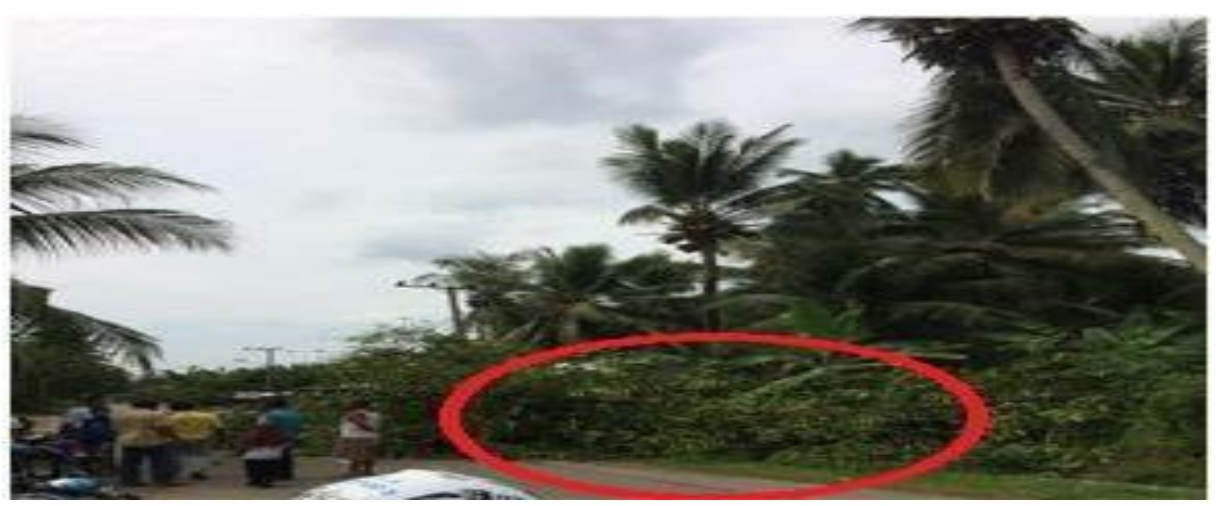

Gambar 4 : Contoh gangguan yang disebabkan oleh pohon

\section{HASIL DAN PEMBAHASAN}

\section{Deskripsi Data}

Tabel 1 : Jenis Pekerjaan dan Bobot Waktu

\begin{tabular}{|c|c|c|}
\hline No & Jenis Pekerjaan & $\begin{array}{c}\text { Bobot } \\
\text { Waktu }\end{array}$ \\
\hline $\mathbf{1}$ & Pemeliharaan jumper atas & 2 jam \\
\hline $\mathbf{2}$ & Pemeliharaan isolator Tumpu & 2 jam \\
\hline $\mathbf{3}$ & Pemeliharaan jumper SUTM & 3 jam \\
\hline $\mathbf{4}$ & Pemeliharaan LBS & 5 jam \\
\hline $\mathbf{5}$ & Pemasangan LBS & 5 jam \\
\hline $\mathbf{6}$ & Pemeliharaan bongkar pasang & 2 jam \\
& recloser & 2 jam \\
\hline $\mathbf{7}$ & Pemeliharaan Block Co \& & \\
\hline $\mathbf{8}$ & Arrester & 2 jam \\
\hline $\mathbf{9}$ & Pemeliharaan Isolator Afspan & 2 jam \\
\hline $\mathbf{1 0}$ & Penyambungangan jaringan baru & 3 jam \\
\hline $\mathbf{1 1}$ & JTM & 3 jam \\
\hline $\mathbf{1 2}$ & Penyambungan Gardu Baru & 2 jam \\
\hline $\mathbf{1 3}$ & Pengamantian arm tie & 2 jam \\
\hline $\mathbf{1 4}$ & Penyambungan jumper SKTM & 2 jam \\
\hline
\end{tabular}




\begin{tabular}{|c|c|c|}
\hline \multicolumn{1}{|c|}{ No } & Jenis Pekerjaan & $\begin{array}{c}\text { Bobot } \\
\text { Waktu }\end{array}$ \\
\hline $\mathbf{1 5}$ & $\begin{array}{c}\text { Rubah SUTM } \\
\text { pentruksi Tumpu ke }\end{array}$ & 2 jam \\
\hline $\mathbf{1 6}$ & $\begin{array}{c}\text { Pemeliharaan Kabel jumper } \\
\text { naik dan turun }\end{array}$ & 2 jam \\
\hline $\mathbf{1 7}$ & Pemeliharaan Kawat rantas & 2 jam \\
\hline $\mathbf{1 8}$ & Pemeliharaan SUTM kendor & 2 jam \\
\hline $\mathbf{1 9}$ & Pemasangan baru penangkap & 2 jam \\
\hline $\mathbf{2 0}$ & Peti & 3 jam \\
\hline $\mathbf{2 1}$ & Pemasangan baru GFD & 2 jam \\
\hline $\mathbf{2 2}$ & Pemeliharan Cross arm & 2 jam \\
\hline $\mathbf{2 3}$ & pemeliharaan set & 2 jam \\
\hline
\end{tabular}

PDKB PT.PLN (Persero) Jawa Barat pada bulan Juni 2020.

Bandung melakukan penelitian ini dengan

jenis pekerjaan dan bobot waktu pengerjaan

Tabel 2 : Jumlah Pekerjaan Bulan Juni

\begin{tabular}{|c|c|c|c|c|c|}
\hline NO & Bulan & $\begin{array}{c}\text { Banyak } \\
\text { Pekerja }\end{array}$ & $\begin{array}{c}\text { Harga } \\
\text { KWh }\end{array}$ & $\begin{array}{c}\text { Banyak } \\
\text { Pelangg } \\
\text { an }\end{array}$ & Cosф \\
\hline $\mathbf{1}$ & Juni & 98 & $\begin{array}{c}\text { Rp. } \\
1206,40\end{array}$ & 883,631 & 0,85 \\
\hline
\end{tabular}

Data dalam tabel ini mewakili jumlah

karyawan, biaya Kwh, jumlah orang yang

bekerja di PDKB Tegangan Menengah pada bulan Juni

2020.

Tabel 3 : Daftar Gardu Induk secara pengukuran

\begin{tabular}{|c|c|c|c|}
\hline No & GarduInduk & Penyulang & Arus \\
\hline $\mathbf{1}$ & CGDG & $\begin{array}{c}\text { Golf dago Cigadung } \\
\text { dago } \\
\text { Bojong kacor }\end{array}$ & 119 \\
\hline $\mathbf{2}$ & CWRA & $\begin{array}{c}\text { Komplek ranca sagatan } \\
\text { fKawaluyaan indah v } \\
\text { Komp.Margahayu raya }\end{array}$ & 72 \\
\hline $\mathbf{3}$ & UZC & $\begin{array}{c}\text { Cipadung no 47 } \\
\text { Cilengkrang } \\
\text { Ah nasution }\end{array}$ & 135 \\
\hline $\mathbf{4}$ & CHB & $\begin{array}{c}\text { Manglid Sekeloa } \\
\text { girang }\end{array}$ & 201 \\
\hline $\mathbf{5}$ & CKSI & Komp.Bumi asri & 60 \\
\hline $\mathbf{6}$ & CKM & $\begin{array}{c}\text { Kopo sayati } \\
\text { Kp sinom kab bandung } \\
\text { Soekarno hatta }\end{array}$ & 141 \\
\hline $\mathbf{7}$ & KPO & Cigadung Awiligar & 83 \\
\hline $\mathbf{8}$ & UGB & $\begin{array}{c}\text { Stasiun Gedebage } \\
\text { Ranca Bolang }\end{array}$ & 81 \\
\hline $\mathbf{9}$ & NAM & Sukamulya & 7 \\
\hline $\mathbf{1 0}$ & CLBR & Sadang & 111 \\
\hline
\end{tabular}




\begin{tabular}{|c|c|c|c|}
\hline No & Gardu Induk & Penyulang & Arus \\
\hline $\mathbf{1 1}$ & USUS & $\begin{array}{c}\text { Soekarno Hatta KK } \\
\text { Singawinata Cikao } \\
\text { Bandung } \\
\text { Arah JCO }\end{array}$ & 39 \\
\hline $\mathbf{1 2}$ & TJSI & Desa Cibiru Wetan & 101 \\
\hline $\mathbf{1 3}$ & WTH & Cibolerang & 74 \\
\hline $\mathbf{1 4}$ & CPDU & $\begin{array}{c}\text { Raya Ah.Nasution } \\
\text { Kom. Madrasah Cibiru } \\
\text { Yayasan Krida } \\
\text { Nusantara } \\
\text { Cibiru Cilengkrang }\end{array}$ & 77 \\
\hline $\mathbf{1 5}$ & CTP & $\begin{array}{c}\text { Citarip Perumahan } \\
\text { Ciganitri }\end{array}$ & 148 \\
\hline
\end{tabular}

Pekerjaan Dalam Keadaan Bertegangan (PDKB) UP3 Bandung mencakup 15 Gardu Induk and 33 penyulang dengan nilai arus yang berbeda, seperti di Tabel 4.3 di atas. Pada Gardu CGDG terdapat 3 penyulang, Gardu CWRA terdapat 3 penyulang, Gardu Induk UZC terdapat 3 penyulang, Gardu Induk CHB terdapat 2 penyulang, Gardu Induk CKSI terdapat 1 penyulang, Gardu Induk CKM terdapat 3 penyulang, Gardu Induk KPO terdapat 1 penyulang, Gardu Induk UGB terdapat 2 penyulang, Gardu Induk NAM terdapat 1 penyulang ,Gardu Induk CBLR terdapat 1 penyulang, Gardu Induk USUS terdapat 4 penyulang,Gardu Induk TJSI terdapat 1 penyulang,Gardu Induk WTH terdapat 1 penyulang,Gardu Induk CPDU terdapat 5 penyulang dan Gardu Induk CTP terdapat 2 penyulang. Tinggi rendahnya arus dipengaruhi oleh titik pekerjaan yang dilakukan tim Pekerjaan Dalam Keadaan Bertegangan(PDKB).

\section{Salah satu Contoh Pengerjaan :}

Besar arus yang mengalir dan long waktu pengerjaan diketahui, dan dengan asumsi tegangan sistem adalah $20 \mathrm{kV}$ Jika cos kurang dari 0,85 , maka perhitungan dapat dilakukan sebagai berikut : Cilengkrang terukur arus yang mengalir sebesar 135 A pada feeder atau penyulang Cilengkrang PDKB pengerjaan untuk isolator tumpu dilakukan dalam 2 jam.

Data di atas dapat dihitung dengan rumus yang berdasarkan persamaan 1 dengan perhitungan energi terselamatkan sebesar:

$$
\begin{aligned}
\text { Esafe } & =\frac{\sqrt{3} \times 20000 \times 135 \times 0,85 \times 2}{1000} \\
& =7.950,11 \mathrm{kWh}
\end{aligned}
$$

Dengan mengalikan besar energy terselamatkan terhadap harga jual listrik PLN Jawa Barat Bandung bulan Juni 2020 sebesar Rp1206,40 maka didapat jumlah rupiah terselamatkan sebesar :

$$
\begin{aligned}
\text { Rpsafe } & =7.950,11 \times 1206,40 \\
& =\operatorname{Rp} 9.591 .016,57
\end{aligned}
$$

Hasilnya, selama proyek pemanenan energi PDKB, total 7.933,33 kWh diproduksi dengan nilai rupiah $\operatorname{Rp} 9.570 .773,33$. Penting untuk dipahami bahwa hasil yang diperoleh dari penelitian ini adalah hasil pengukuran. 
Tabel 4 : Daftar Gardu Induk secara perhitungan

\begin{tabular}{|c|c|c|c|}
\hline No & $\begin{array}{l}\text { Gardu } \\
\text { Induk }\end{array}$ & Penyulang & Arus \\
\hline 1 & CGDG & Golf dago Cigadung dagoBojong kacor & 75 \\
\hline 2 & CWRA & $\begin{array}{c}\text { Komplek ranca sagatan fKawaluyaan indah v } \\
\text { Komp.Margahayu raya }\end{array}$ & 115 \\
\hline 3 & $\mathrm{UZC}$ & $\begin{array}{c}\text { Cipadung no 47Cilengkrang } \\
\text { Ah nasution }\end{array}$ & 214 \\
\hline 4 & CHB & Manglid Sekeloa girang & 127 \\
\hline 5 & CKSI & Komp.Bumi asri & 94 \\
\hline 6 & CKM & $\begin{array}{c}\text { Kopo sayati } \\
\text { Kp sinom kab bandung Soekarno hatta }\end{array}$ & 94 \\
\hline 7 & KPO & Cigadung Awiligar & 132 \\
\hline 8 & UGB & $\begin{array}{l}\text { Stasiun Gedebage } \\
\text { Ranca Bolang }\end{array}$ & 129 \\
\hline 9 & NAM & Sukamulya & 107 \\
\hline 10 & CLBR & Sadang & 264 \\
\hline 11 & USUS & $\begin{array}{l}\text { Soekarno HattaKK SingawinataCikao } \\
\text { Bandung } \\
\text { Arah JCO }\end{array}$ & 61 \\
\hline 12 & TJSI & Desa Cibiru Wetan & 160 \\
\hline 13 & WTH & Cibolerang & 118 \\
\hline 14 & CPDU & $\begin{array}{c}\text { Raya Ah.Nasution Kom. Madrasah Cibiru } \\
\text { Yayasan Krida Nusantara } \\
\text { Cibiru Cilengkrang }\end{array}$ & 122 \\
\hline 15 & CTP & Citarip Perumahan Ciganitri & 235 \\
\hline
\end{tabular}

Dapat diketahui bahwa Pekerjaan Dalam Keadaan Bertegangan (PDKB) Area Bandung terdapat 15 Gardu Induk dan 33 penyulang dengan nilai arus yang berbeda. pada Gardu CGDG terdapat 3 penyulang, Gardu CWRA terdapat 3 penyulang, Gardu Induk UZC terdapat 3 penyulang, Gardu Induk CHB terdapat 2 penyulang, Gardu Induk CKSI terdapat 1 penyulang, Gardu Induk CKM terdapat 3 penyulang, Gardu Induk KPO terdapat 1 penyulang, Gardu Induk UGB terdapat 2 penyulang, Gardu Induk NAM terdapat 1 penyulang, Gardu Induk CBLR terdapat 1 penyulang, Gardu
Induk USUS terdapat 4 penyulang,Gardu Induk TJSI terdapat 1 penyulang,Gardu Induk WTH terdapat 1 penyulang,Gardu Induk CPDU terdapat 5 penyulang dan Gardu Induk CTP terdapat 2 penyulang. Tinggi rendahnya arus dilakukan oleh titik pekerjaan yang dilakukan oleh tim Pekerjaan Dalam Keadaan Bertegangan (PDKB). Nilai Energi terselamatkan dan Nilai Rupiah yang terselamatkan pada penyulang cara: Dengan asumsi bahwa sistem tegangan adalah $20 \mathrm{kV}$ dan cos kurang dari 0,85 , perhitungan dapat dilakukan sebagai berikut :

Pengerjaan PDKB untuk pemeliharaan 
isolator tumpu dilakukan selama 2 jam pada feeder atau penyulang Cilengkrang terukur arus yang mengalir sebesar 214 A dan pengerjaan PDKB untuk pemeliharaan isolator tumpu dilakukan selama 2 jam. Data di atas dapat dihitung dengan rumus berdasarkan persamaan 1 dengan energi terselamatkan sebesar :

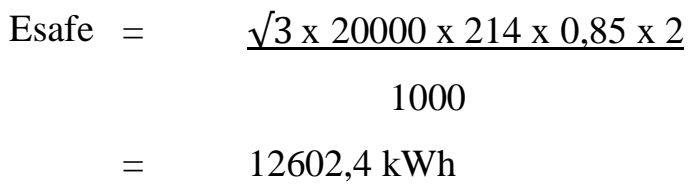
terselamatkan terhadap harga jual listrik PLN UP3 Bandung bulan Juni 2020 sebesar Rp1206,40 maka didapat jumlah rupiah terselamatkan sebesar :

$$
\begin{aligned}
\text { Rpsafe } & =12602,4 \times 1206,40 \\
& =\operatorname{Rp} 15.203 .535,36
\end{aligned}
$$

Jadi pada kegiatan pemeliharaan yang dilakukan Hasilnya, PDKB menerima energi 12.602,4 kWh dengan nilai Rupiah Rp 15.203.535,36. tidak hanya satu kegiatan pemeliharaan JTM yang dilakukan tim PDKB TM UP3 Bandung pada penyulang penyulang lain pada bulan Juni 2020 yang berjumlah 80 pekerjaan yang hampir sama dengan hasilyang berbeda. Serta perhitungan ini adalah satu dari sekian banyak pekerjaan pada bulan Juni 2020. Data yang sudah ada dapat dihitung dan dianalisis dengan rumus yang ada, Pekerjaan Dalam Keadaan Bertegangan adalah kegiatan penjumperan dan pemasangan JTM yang dilakukan (PDKB).

\begin{tabular}{|c|c|c|c|c|c|c|}
\hline No & Tanggal & Jenis Pekerjaan & $\begin{array}{c}\text { Arus } \\
\text { Saluran } \\
\text { (Ampere) }\end{array}$ & $\begin{array}{c}\text { Standar } \\
\text { Waktu } \\
\text { Offline } \\
\text { (Jam) }\end{array}$ & $\begin{array}{l}\text { Harga } \\
\text { kWh }\end{array}$ & $\operatorname{Cos} \phi$ \\
\hline 1 & 03-Jun-20 & $\begin{array}{c}\text { PEMELIHARAAN ISOLATOR } \\
\text { TUMPU FASA } \\
\text { R,S CGDG } 20\end{array}$ & 119 & 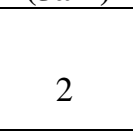 & Rp. 1206,40 & 0,85 \\
\hline 2 & 03-Jun-20 & $\begin{array}{c}\text { PEMELIHARAAN ISOLATOR } \\
\text { TUMPU FASA } \\
\text { R,S CGDG } 21 \\
\end{array}$ & 119 & 2 & Rp.1206,40 & 0,85 \\
\hline 3 & 03-Jun-20 & $\begin{array}{c}\text { PEMELIHARAAN ISOLATOR } \\
\text { TUMPU FASA R } \\
\text { CWRA } 110\end{array}$ & 72 & 2 & Rp.1206,40 & 0,85 \\
\hline 4 & 03-Jun-20 & $\begin{array}{c}\text { PEMELIHARAAN JUMPER } \\
\text { AFTAK } \\
\text { KIEA }\end{array}$ & 72 & 2 & Rp.1206,40 & 0,85 \\
\hline 5 & 04-Jun-20 & $\begin{array}{c}\text { PEMELIHARAAN ISOLATOR } \\
\text { TUMPU FASA T CWRA } 108\end{array}$ & 72 & 2 & Rp. 1206,40 & 0,85 \\
\hline 6 & 04-Jun-20 & $\begin{array}{c}\text { PEMELIHARAAN ISOLATOR } \\
\text { TUMPU ARAH GARDU CPR }\end{array}$ & 135 & 2 & Rp.1206,40 & 0,85 \\
\hline 7 & 05-Jun-20 & $\begin{array}{c}\text { PENJUMPERAN JARINGAN } \\
\text { BARU ARAH } \\
\text { GARDU CPRA } \\
\end{array}$ & 135 & 3 & Rp.1206,40 & 0,85 \\
\hline 8 & 05-Jun-20 & $\begin{array}{c}\text { BUKA PASANG JUMPER } \\
\text { KABEL TURUN GARDU ITD } \\
\text { ARAH PENY. } \\
\text { CHB } \\
\end{array}$ & 201 & 2 & Rp.1206,40 & 0,85 \\
\hline
\end{tabular}

Tabel 5 : Jumlah pekerjaan PDKB selama sebulan dengan Pengukuran 


\begin{tabular}{|c|c|c|c|c|c|c|}
\hline No & Tanggal & Jenis Pekerjaan & $\begin{array}{c}\text { Arus } \\
\text { Saluran } \\
\text { (Ampere) }\end{array}$ & $\begin{array}{l}\text { Standar } \\
\text { Waktu } \\
\text { Offline } \\
\text { (Jam) }\end{array}$ & $\begin{array}{l}\text { Harga } \\
\text { kWh }\end{array}$ & $\operatorname{Cos} \phi$ \\
\hline 9 & 05-Jun-20 & $\begin{array}{c}\text { PEMELIHARAAN ISOLATOR } \\
\text { ASFAN MENDESIS } \\
\text { CWRA 17L16 }\end{array}$ & 72 & 2 & Rp. 1206,40 & 0,85 \\
\hline 10 & 05-Jun-20 & $\begin{array}{c}\text { PEMBUKAAN } \\
\text { JUMPER ARAH GARDU BAM }\end{array}$ & 60 & 2 & Rp. 1206,40 & 0,85 \\
\hline
\end{tabular}

Jumlah Pekerjaan PDKB Selama 1 Bulan dengan keterangan Tanggal Pengerjaan, Jenis Pekerjaan, Arus Penyulang, Waktu Pengerjaan, Harga PerKwh pada bulan Juni, dan Faktor Daya, dapat diketahui Bobot Waktu yang dilakukan selama pengerjaan PDKB yaitu 2, 3, 5 dalam satuan jam di PT.PLN Persero Jawa Barat Bandung.

\section{Contoh Perhitungan Data Harian}

Dengan asumsi bahwa sistem tegangan adalah $20 \mathrm{kV}$ dan cos kurang dari 0,85, perhitungan dapat dilakukan sebagai berikut : CGDG terukur arus yang mengalir sebesar 119 A pada feeder atau penyulang. And PDKB pengerjaan untuk isolator tumpu dilakukan selama 2 jam. Data di atas dapat dihitung dengan rumus berdasarkan persamaan 1 dengan energi terselamatkan sebesar :

$$
\begin{aligned}
\text { Esafe } & =\sqrt{3 \times 20000 \times 119 \times 0,85 \times 2} \\
1000 & \\
& =7.007,87 \mathrm{kWh}
\end{aligned}
$$

Dengan mengalikan besar energy terselamatkan terhadap harga jual listrik PLN UP3 Bandung bulan Juni 2020 sebesar Rp1206,40 maka didapat jumlah rupiah terselamatkan sebesar :

$$
\begin{aligned}
\text { Rpsafe } & =7.007,87 \times 1206,40 \\
& =\operatorname{Rp~8.454.294,68~}
\end{aligned}
$$

Pada kegiatan pemeliharaan yang dilakukan PDKB didapat energy terselamatkan sebesar $7.007,87 \mathrm{kWh}$. Hasil diatas adalah salah satu contoh dari sekian banyak pekerjaan.

Tabel 6 : Hasil Perhitungan Energi Terselamatkan Per Hari dengan Pengukuran

\begin{tabular}{|r|c|c|c|c|}
\hline NO & Tanggal & $\begin{array}{c}\text { Arus } \\
\text { Saluran } \\
\text { (Ampere) }\end{array}$ & $\begin{array}{c}\text { Standar } \\
\text { Waktu } \\
\text { Offline } \\
\text { (Jam) }\end{array}$ & $\begin{array}{c}\text { KWH } \\
\text { Terselamatkan }\end{array}$ \\
\hline $\mathbf{1}$ & 03-Jun-20 & 119 & 2 & $7.033,75$ \\
\hline $\mathbf{2}$ & 03-Jun-20 & 119 & 2 & $7.033,75$ \\
\hline $\mathbf{3}$ & 03-Jun-20 & 72 & 2 & $4.264,17$ \\
\hline $\mathbf{4}$ & 03-Jun-20 & 72 & 2 & $4.264,17$ \\
\hline $\mathbf{5}$ & 04-Jun-20 & 72 & 2 & $4.264,17$ \\
\hline $\mathbf{6}$ & 04-Jun-20 & 135 & 2 & $7.933,33$ \\
\hline $\mathbf{7}$ & 05-Jun-20 & 135 & 2 & $11.900,00$ \\
\hline $\mathbf{8}$ & 05-Jun-20 & 201 & & $11.822,08$ \\
\hline
\end{tabular}




\begin{tabular}{|r|c|c|c|c|}
\hline $\mathbf{9}$ & 05-Jun-20 & 72 & 2 & $4.264,17$ \\
\hline $\mathbf{1 0}$ & 05-Jun-20 & 60 & 2 & $3.516,17$ \\
\hline
\end{tabular}

Bahwa data harian Energi Terselamatkan yangdi dapat pada bulan Juni 2020 penuh di
PT.PLN Persero Unit Induk Distribusi Jawa

Barat UP3 Bandung.

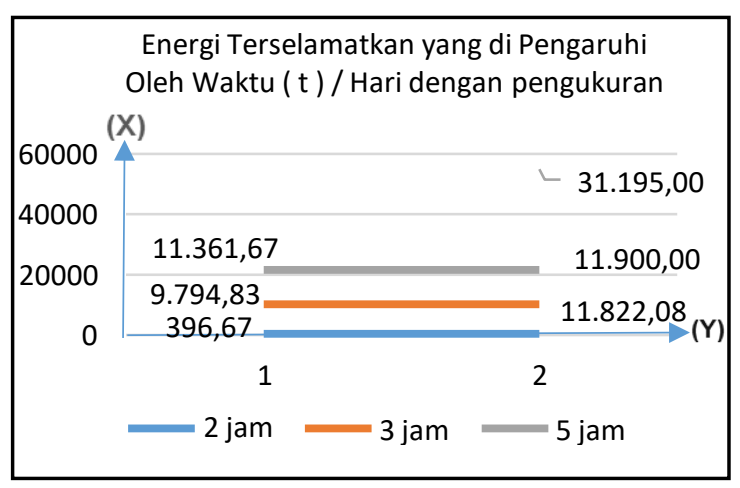

Gambar 5 : Grafik Energi Terselamatkan / Hari

Grafik di atas menunjukan hubungan Energi Terselematkan terhadap waktu perhari pada pengerjaan PDKB dalam waktu Bulan Juni 2020. Sumbu $X$ merepresentasikan nilai energi terselamatkan yang ditunjukan pada kurva diatas, Sedangkan sumbu $\mathrm{Y}$ merepresentasikan besar lama waktu pengerjaan PDKB. Diketahui bahwa nilai Energi Terselamatkan yang terkecil sampai yang terbesar dari waktu pengerjaan 2 jam adalah 396,67 s/d 11.822,08, waktu pengerjaan 3 jam adalah 9.794,83 s/d 11.900,00, dan waktu Pengerjaan 5jam adalah 11.361,67 s/d 31.195,00.

\section{Tabel 7 : Hasil Perhitungan Rupiah TerselamatkanPer Hari dengan Pengukuran}

\begin{tabular}{|c|c|c|c|}
\hline NO & Tanggal & $\begin{array}{c}\text { Standar } \\
\text { Waktu } \\
\text { Offline } \\
\text { (Jam) }\end{array}$ & $\begin{array}{c}\text { Rp } \\
\text { Terselamatkan }\end{array}$ \\
\hline $\mathbf{1}$ & 03-Jun-20 & 2 & $8.485 .516,00$ \\
\hline $\mathbf{2}$ & 03-Jun-20 & 2 & $8.485 .516,00$ \\
\hline $\mathbf{3}$ & 03-Jun-20 & 2 & $5.144 .290,67$ \\
\hline $\mathbf{4}$ & 03-Jun-20 & 2 & $5.144 .290,67$ \\
\hline $\mathbf{5}$ & 04-Jun-20 & 2 & $5.144 .290,67$ \\
\hline $\mathbf{6}$ & 04-Jun-20 & 2 & $9.570 .773,33$ \\
\hline $\mathbf{7}$ & 05-Jun-20 & 3 & $14.356 .160,00$ \\
\hline $\mathbf{8}$ & 05-Jun-20 & 2 & $14.262 .161,33$ \\
\hline $\mathbf{9}$ & 05-Jun-20 & 2 & $5.144 .290,67$ \\
\hline $\mathbf{1 0}$ & 05-Jun-20 & 2 & $4.241 .903,47$ \\
\hline
\end{tabular}

Dari data diatas menunjukan bahwa data harian Rupiah Terselamatkan yang di dapat pada bulan Juni 2020 penuh di PT.PLN
Persero Unit Induk Distribusi Jawa Barat UP3 Bandung. 


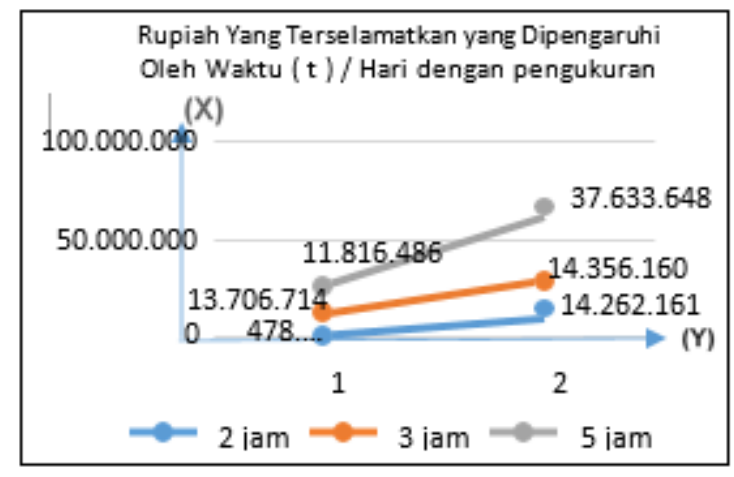

Gambar 6 : Grafik Rupiah Terselamatkan/Hari dengan pengukuran

Grafik di atas menunjukan hubungan Rupiah Terselematkan terhadap waktu perhari pada pengerjaan PDKB dalam waktu Bulan Juni 2020. Sumbu $X$ merepresentasikan nilai energi terselamatkan yang ditunjukan pada kurva diatas, Sedangkan sumbu $\mathrm{Y}$ merepresentasikan besar lama waktu pengerjaan PDKB.
Diketahui bahwa nilai Energi Terselamatkan yang terkecil sampai yang terbesar dari waktu pengerjaan 2 jam adalah 478.538,67 s/d 14.262.161,33, waktu pengerjaan 3 jam adalah $11.816 .486,93 \quad$ s/d 14.356.160,00 dan waktu pengerjaan 5 jam adalah 13.706.714,67 s/d 37.633.648,00.

Tabel 8 : Hasil Perhitungan Energi dan Rupiahterselamatkan dengan Pengukuran

\begin{tabular}{|c|c|c|c|c|}
\hline $\mathbf{N o}$ & $\begin{array}{l}\text { Arus } \\
\text { (Ampere) }\end{array}$ & $\begin{array}{l}\text { Lama } \\
\text { Pengerjaan }\end{array}$ & $\begin{array}{c}\text { Energi } \\
\text { Terselamatkan } \\
\text { ( KWH })\end{array}$ & $\begin{array}{c}\text { Prakiraan } \\
\text { Rupiah yang } \\
\text { Terselamatkan }\end{array}$ \\
\hline $\mathbf{1}$ & 119 & 5 jam & $17.584,38$ & $21.213 .790,00$ \\
\hline $\mathbf{2}$ & 72 & 2 jam & $4.264,17$ & $5.144 .290,67$ \\
\hline $\mathbf{3}$ & 135 & 5 jam & $19.833,33$ & $23.926 .933,33$ \\
\hline $\mathbf{4}$ & 201 & 2 jam & $11.822,08$ & $14.262 .161,33$ \\
\hline $\mathbf{5}$ & 60 & 2 jam & $3.516,17$ & $4.241 .903,47$ \\
\hline $\mathbf{6}$ & 141 & 5 jam & $20.740,00$ & $25.020 .736,00$ \\
\hline $\mathbf{7}$ & 83 & 5 jam & $12.268,33$ & $14.800 .517,33$ \\
\hline $\mathbf{8}$ & 81 & 5 jam & $11.992,08$ & $14.467 .249,33$ \\
\hline $\mathbf{9}$ & 7 & 2 jam & 396,67 & $478.538,67$ \\
\hline $\mathbf{1 0}$ & 111 & 3 jam & $9.794,83$ & $11.816 .486,93$ \\
\hline $\mathbf{1 1}$ & 39 & 2 jam & $2.269,50$ & $2.737 .924,80$ \\
\hline $\mathbf{1 2}$ & 101 & 5 jam & $14.818,33$ & $17.876 .837,33$ \\
\hline $\mathbf{1 3}$ & 74 & 2 jam & $4.374,67$ & $5.277 .597,87$ \\
\hline $\mathbf{1 4}$ & 77 & 5 jam & $11.361,67$ & $13.706 .714,67$ \\
\hline $\mathbf{1 5}$ & 148 & 5 jam & $21.816,67$ & $26.319 .626,67$ \\
\hline
\end{tabular}

Dapat dihitung total energi terselamatkan dalam 1 bulan pengerjaan PDKB adalah sebesar 510.260,43 KWh (Kilo Watt hour) dan jika ditafsirkan ke dalam rupiah sekitar 615.578.183,42 rupiah. 


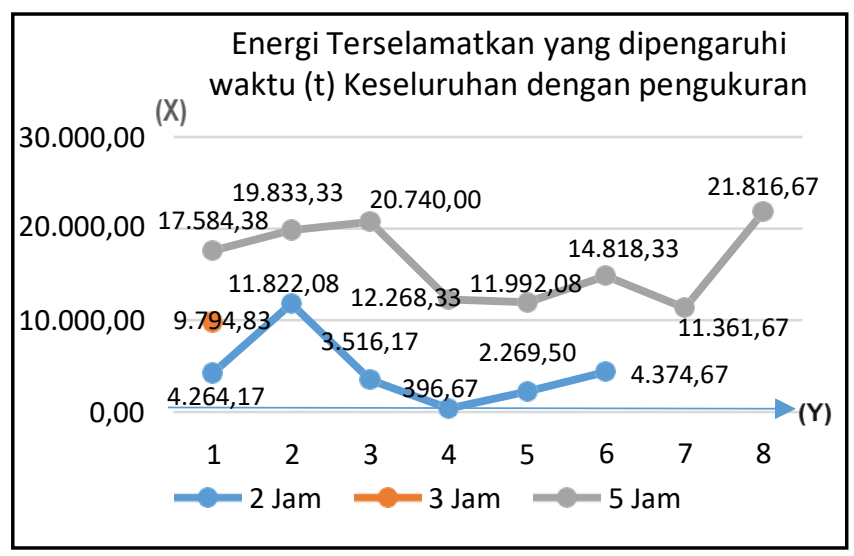

\section{Gambar 7 : Grafik hubungan Energi terselamatkanterhadap lama pengerjaan PDKB}

Grafik diatas menunjukan hubungan waktu pengerjaan PDKB pada kurva diatas perkiraan rupiah terselamatkan terhadap arus dapat dilihat bahwa, semakin lama dan lama pengerjaan PDKB.) sumbu $X$ pengerjaan semakin besar juga nilai rupiah menunjukan nilai rupiah terselamatkan, yang

terselamatkan.

Sedangkan sumbu Y merepresentasikan lama

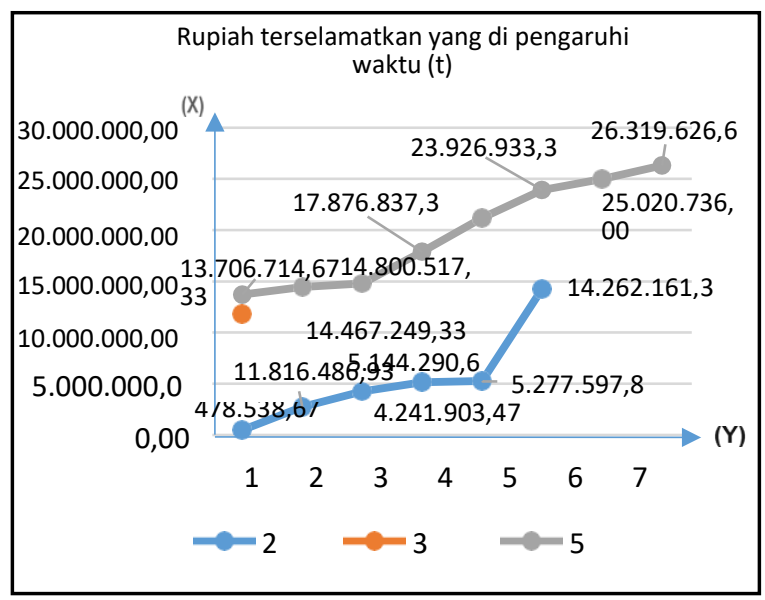

Gambar 8 : Garfik hubungan perkiraan rupiah Terselamatkan terhadap lama pengerjaan PDKB

Grafik diatas menunjukan hubungan perkiraan rupiah terselamatkan terhadap arus dan lama pengerjaan PDKB.) sumbu $X$ menunjukan nilai rupiah terselamatkan, Sedangkan sumbu Y merepresentasikan lama waktu pengerjaan PDKB pada kurva diatas dapat dilihat bahwa, semakin lama pengerjaan semakin besar juga nilai rupiah yang terselamatkan. 
Tabel 9 : Jumlah pekerjaan PDKB selamasebulan dengan perhitungan

\begin{tabular}{|c|c|c|c|c|c|c|}
\hline NO & Tanggal & Jenis Pekerjaan & $\begin{array}{c}\text { Arus } \\
\text { Saluran } \\
\text { (Ampere) }\end{array}$ & $\begin{array}{c}\text { Standar } \\
\text { Waktu } \\
\text { Offline(Jam) }\end{array}$ & $\begin{array}{l}\text { Harga } \\
\text { kWh }\end{array}$ & $\operatorname{Cos} \phi$ \\
\hline 1 & 03-Jun-20 & $\begin{array}{c}\text { PEMELIHARAAN } \\
\text { ISOLATOR TUMPU FASA R,S } \\
\text { CGDG } 20\end{array}$ & 75 & 2 & Rp. 1206,40 & 0,85 \\
\hline 2 & 03-Jun-20 & $\begin{array}{c}\text { PEMELIHARAAN ISOLATOR } \\
\text { TUMPU FASA } \\
\text { R,S CGDG } 21 \\
\end{array}$ & 75 & 2 & Rp. 1206,40 & 0,85 \\
\hline 3 & 03-Jun-20 & $\begin{array}{l}\text { PEMELIHARAAN ISOLATOR } \\
\text { TUMPU FASA R CWRA } 110\end{array}$ & 115 & 2 & Rp.1206,40 & 0,85 \\
\hline 4 & 03-Jun-20 & $\begin{array}{l}\text { PEMELIHARAAN JUMPER AFTAK } \\
\text { KIEA }\end{array}$ & 115 & 2 & Rp.1206,40 & 0,85 \\
\hline 5 & 04-Jun-20 & $\begin{array}{c}\text { PEMELIHARAAN ISOLATOR } \\
\text { TUMPU FASA T } \\
\text { CWRA } 108 \\
\end{array}$ & 115 & 2 & Rp.1206,40 & 0,85 \\
\hline 6 & 04-Jun-20 & $\begin{array}{c}\text { PEMELIHARAAN ISOLATOR } \\
\text { TUMPU ARAH GARDU CPR }\end{array}$ & 214 & 2 & Rp.1206,40 & 0,85 \\
\hline 7 & 05-Jun-20 & $\begin{array}{c}\text { PENJUMPERAN JARINGAN BARU } \\
\text { ARAH } \\
\text { GARDU CPRA }\end{array}$ & 214 & 3 & Rp.1206,40 & 0,85 \\
\hline 8 & 05-Jun-20 & $\begin{array}{c}\text { BUKA PASANG JUMPER KABEL } \\
\text { TURUN GARDU ITD ARAH PENY. } \\
\text { CHB }\end{array}$ & 127 & 2 & Rp. 1206,40 & 0,85 \\
\hline 9 & 05-Jun-20 & $\begin{array}{c}\text { PEMELIHARAAN ISOLATOR } \\
\text { ASFAN MENDESIS } \\
\text { CWRA 17L16 } \\
\end{array}$ & 115 & 2 & Rp. 1206,40 & 0,85 \\
\hline 10 & 05-Jun-20 & $\begin{array}{c}\text { PEMBUKAAN } \\
\text { JUMPER ARAH GARDU BAM }\end{array}$ & 94 & 2 & Rp.1206,40 & 0,85 \\
\hline
\end{tabular}

\section{Contoh Perhitungan Data Harian}

Dengan asumsi bahwa sistem tegangan adalah $20 \mathrm{kV}$ dan cos kurang dari 0,85 , perhitungan berikut dapat dilakukan: Pada pengumpan atau penyulang CGDG terukur arus yang mengalir sebesar 75 A. Dan pengerjaan PDKB untuk pemeliharaan isolator tumpu dilakukan selama 2 jam. Dari data di atas dapat dihitung dengan rumus berdasarkan persamaan 1 dengan perhitungan energiterselamatkan sebesar :

$$
\begin{aligned}
\text { Esafe } & =\frac{\sqrt{3} \times 20000 \times 75 \times 0,85 \times 2}{1000} \\
& =4416,72 \mathrm{kWh}
\end{aligned}
$$

Dengan mengalikan besar energy terselamatkan terhadap harga jual listrik PLN UP3 Bandung bulan Juni 2020 sebesar Rp1206,40 maka didapat jumlah rupiah terselamatkan sebesar:

$$
\begin{aligned}
\text { Rpsafe } & =4416,72 \times 1206,40 \\
& =\operatorname{Rp} 5.328 .342,54
\end{aligned}
$$

Pada kegiatan pemeliharaan yang dilakukan PDKB didapat energy terselamatkan sebesar 4416,72 kWh. Perhitungan diatas adalah salah satu contoh dari sekian banyak pekerjaan pada bulan Juni 2020 dengan menggunakan perhitungan. 
Tabel 10 : Hasil Perhitungan Energi TerselamatkanPer Hari Secara perhitungan

\begin{tabular}{|c|c|c|c|c|}
\hline NO & Tanggal & $\begin{array}{c}\text { Arus Saluran } \\
\text { (Ampere) }\end{array}$ & $\begin{array}{c}\text { Standar } \\
\text { Waktu Offline } \\
\text { (Jam) }\end{array}$ & $\begin{array}{c}\text { KWH } \\
\text { Terselamatka } \\
\mathbf{n}\end{array}$ \\
\hline $\mathbf{1}$ & 03-Jun-20 & 75 & 2 & $4.416,72$ \\
\hline $\mathbf{2}$ & 03-Jun-20 & 75 & 2 & $4.416,72$ \\
\hline $\mathbf{3}$ & 03-Jun-20 & 115 & 2 & $6.772,31$ \\
\hline $\mathbf{4}$ & 03-Jun-20 & 115 & 2 & $6.772,31$ \\
\hline $\mathbf{5}$ & 04-Jun-20 & 115 & 2 & $6.772,31$ \\
\hline $\mathbf{6}$ & 04-Jun-20 & 214 & 2 & $12.602,40$ \\
\hline $\mathbf{7}$ & 05-Jun-20 & 214 & 3 & $18.903,60$ \\
\hline $\mathbf{8}$ & 05-Jun-20 & 127 & 2 & $7.478,99$ \\
\hline $\mathbf{9}$ & 05-Jun-20 & 115 & 2 & $6.772,31$ \\
\hline $\mathbf{1 0}$ & 05-Jun-20 & 94 & 2 & $5.535,63$ \\
\hline
\end{tabular}

Dari data tabel diatas menunjukan bahwa data harian Energi Terselamatkan yang di dapat pada bulan Juni 2020 penuh di PT.PLN
Persero Unit Induk Distribusi Jawa Barat UP3 Bandung dengan menggunakan perhitungan.

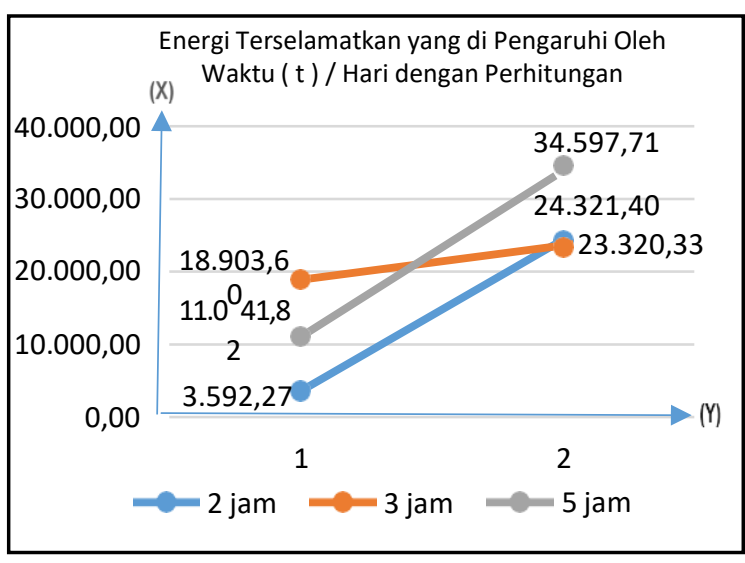

Gambar 9 : Grafik Hubungan Energi Terselamatkan / Hari dengan Perhitungan

Grafik di atas menunjukan hubungan Energi

Terselematkan terhadap waktu perhari pada pengerjaan PDKB dalam waktu Bulan Juni 2020. Sumbu $X$ merepresentasikan nilai energi terselamatkan yang ditunjukan pada kurva diatas, Sedangkan sumbu $\mathrm{Y}$ merepresentasikan besar lama waktu pengerjaan PDKB. Diketahui bahwa nilai
Energi Terselamatkan yang terkecil sampai yang terbesar dari waktu pengerjaan 2 jam adalah $3.592,27 \quad$ s/d $24.321,40$, waktu pengerjaan 3 jam adalah 18.903,60 s/d 23.320,33, dan waktu pengerjaan 5 jam adalah $11.041,82 \mathrm{~s} / \mathrm{d} 34.597,71$. 
Tabel 11 : Hasil Perhitungan RupiahTerselamatkan Per Hari

\begin{tabular}{|c|c|c|c|}
\hline NO & Tanggal & $\begin{array}{c}\text { Standar Waktu } \\
\text { Offline (Jam) }\end{array}$ & $\begin{array}{c}\text { Rp } \\
\text { Terselamatkan }\end{array}$ \\
\hline $\mathbf{1}$ & 03-Jun-20 & 2 & $5.328 .331,01$ \\
\hline $\mathbf{2}$ & 03-Jun-20 & 2 & $5.328 .331,00$ \\
\hline $\mathbf{3}$ & 03-Jun-20 & 2 & $8.170 .114,78$ \\
\hline $\mathbf{4}$ & 03-Jun-20 & 2 & $8.170 .114,78$ \\
\hline $\mathbf{5}$ & 04-Jun-20 & 2 & $8.170 .114,78$ \\
\hline $\mathbf{6}$ & 04-Jun-20 & 2 & $15.203 .535,36$ \\
\hline $\mathbf{7}$ & 05-Jun-20 & 3 & $22.805 .303,04$ \\
\hline $\mathbf{8}$ & 05-Jun-20 & 2 & $9.022 .653,54$ \\
\hline $\mathbf{9}$ & 05-Jun-20 & 2 & $8.170 .114,78$ \\
\hline $\mathbf{1 0}$ & 05-Jun-20 & 2 & $6.678 .184,03$ \\
\hline
\end{tabular}

Tabel diatas menunjukan bahwa data harian

Unit Induk Distribusi Jawa Barat UP3 Rupiah Terselamatkan yang di dapat pada Bandung. bulan Juni 2020 penuh di PT.PLN Persero

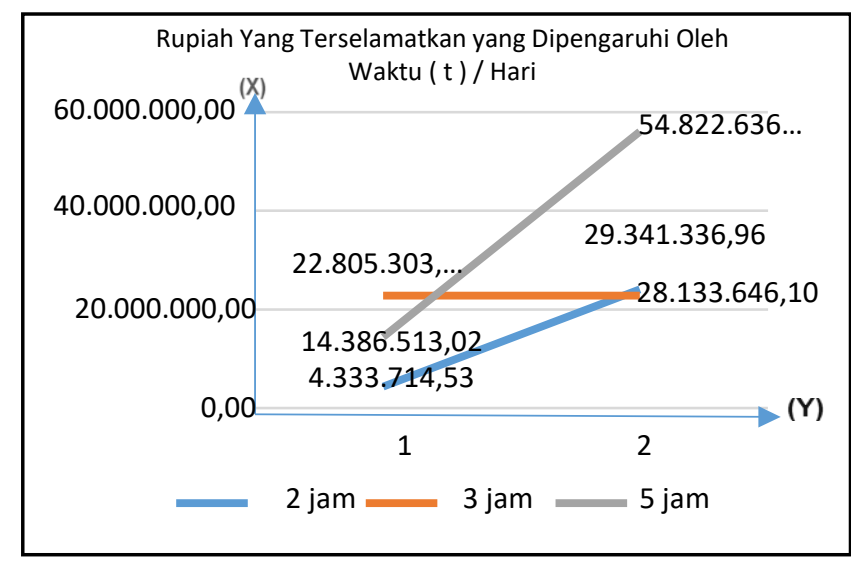

Gambar 10 : Grafik Hubungan Rupiah Terselamatkan / Hari dengan Perhitungan

Gambar di atas menunjukan hubungan Rupiah Terselematkan terhadap waktu perhari pada pengerjaan PDKB dalam waktu Bulan Juni 2020. Sumbu X merepresentasikan nilai energi terselamatkan yang ditunjukan pada kurva diatas, Sedangkan sumbu $\mathrm{Y}$ merepresentasikan besar lama waktu pengerjaan PDKB.
Diketahui bahwa nilai Energi Terselamatkan yang terkecil sampai yang terbesar dari waktu pengerjaan 2 jam adalah 4.333.714,53 s/d 29.341.336,96, waktu pengerjaan 3 jam adalah $22.805 .303,04 \quad$ s/d $28.133 .646,11$ dan waktu pengerjaan 5 jam adalah 14.386.513,02 s/d 54.822.636,30. 
Tabel 12 : Hasil Perhitungan Energi dan Rupiah terselamatkan dengan perhitungan

\begin{tabular}{|c|c|c|c|c|}
\hline No & $\begin{array}{c}\text { Arus } \\
\text { (Ampere) }\end{array}$ & $\begin{array}{c}\text { Lama } \\
\text { Pengerjaan } \\
\text { (Lama })\end{array}$ & $\begin{array}{c}\text { Energi } \\
\text { Terselamatkan } \\
\text { (KWH })\end{array}$ & $\begin{array}{c}\text { Prakiraan Rupiah } \\
\text { yang } \\
\text { Terselamatkan }\end{array}$ \\
\hline $\mathbf{1}$ & 75 & 5 jam & $11.041,82$ & $54.822 .636,30$ \\
\hline $\mathbf{2}$ & 115 & 2 jam & $6.772,31$ & $8.170 .114,78$ \\
\hline $\mathbf{3}$ & 214 & 5 jam & $31.506,00$ & $38.008 .838,40$ \\
\hline $\mathbf{4}$ & 127 & 2 jam & $7.478,99$ & $9.022 .653,54$ \\
\hline $\mathbf{5}$ & 94 & 2 jam & $5.535,63$ & $6.678 .184,03$ \\
\hline $\mathbf{6}$ & 94 & 5 jam & $13.839,08$ & $16.695 .466,11$ \\
\hline $\mathbf{7}$ & 132 & 5 jam & $19.433,61$ & $23.444 .707,10$ \\
\hline $\mathbf{8}$ & 129 & 5 jam & $7.596,77$ & $9.164 .743,33$ \\
\hline $\mathbf{9}$ & 107 & 2 jam & $6.301,02$ & $7.601 .550,53$ \\
\hline $\mathbf{1 0}$ & 264 & 3 jam & $23.320,33$ & $28.133 .646,11$ \\
\hline $\mathbf{1 1}$ & 61 & 2 jam & $3.592,27$ & $4.333 .714,53$ \\
\hline $\mathbf{1 2}$ & 160 & 5 jam & $23.555,89$ & $28.417 .825,70$ \\
\hline $\mathbf{1 3}$ & 118 & 2 jam & $6.948,98$ & $8.383 .249,47$ \\
\hline $\mathbf{1 4}$ & 122 & 5 jam & $17.691,36$ & $21.342 .856,70$ \\
\hline $\mathbf{1 5}$ & 235 & 5 jam & $34.597,71$ & $41.738 .677,34$ \\
\hline
\end{tabular}

Dari Tabel Diatas, dapat dihitung total energi terselamatkan dalam 1 bulan pengerjaan PDKB secara perhitungan adalah sebesar
678.477,24 KWh (Kilo Watt hour) dan jika ditafsirkan ke dalam rupiah sekitar 835.435.301,46 rupiah

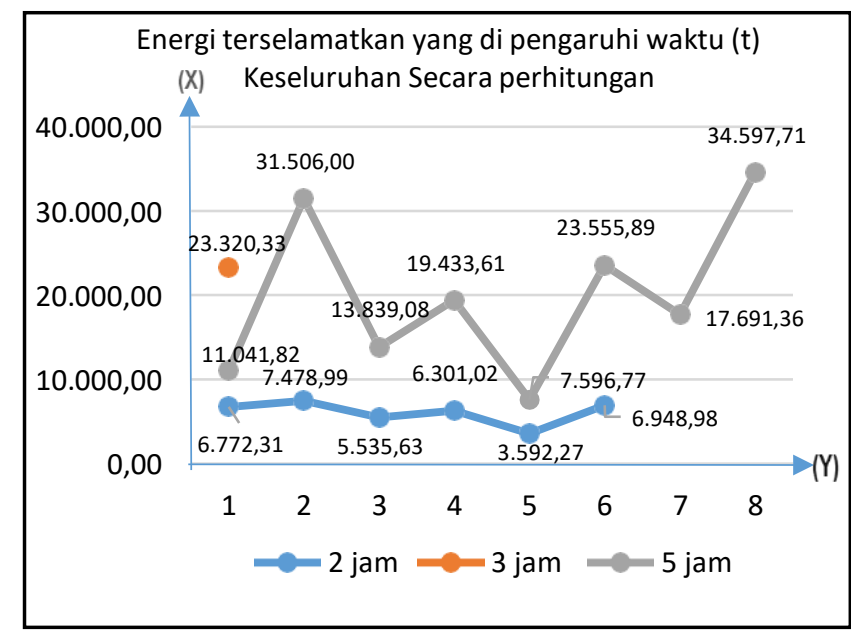

Gambar 11 : Grafik Energi terselamatkankeseluruhan Secara perhitungan

Grafik diatas Menunjukkan hubungan energi terselamatkan terhadap lama pengerjaan PDKB. sumbu $X$ merepresentasikan nilai energi terselamatkan yang ditunjukan pada kurva diatas, Sedangkan sumbu Y merepresentasikan besar lama waktu pengerjaan PDKB.

Maka semakin lama pengerjaan PDKB maka semakinbesar kwh yang diselamatkan hal ini bisa dilihat pada kurva diatas. 


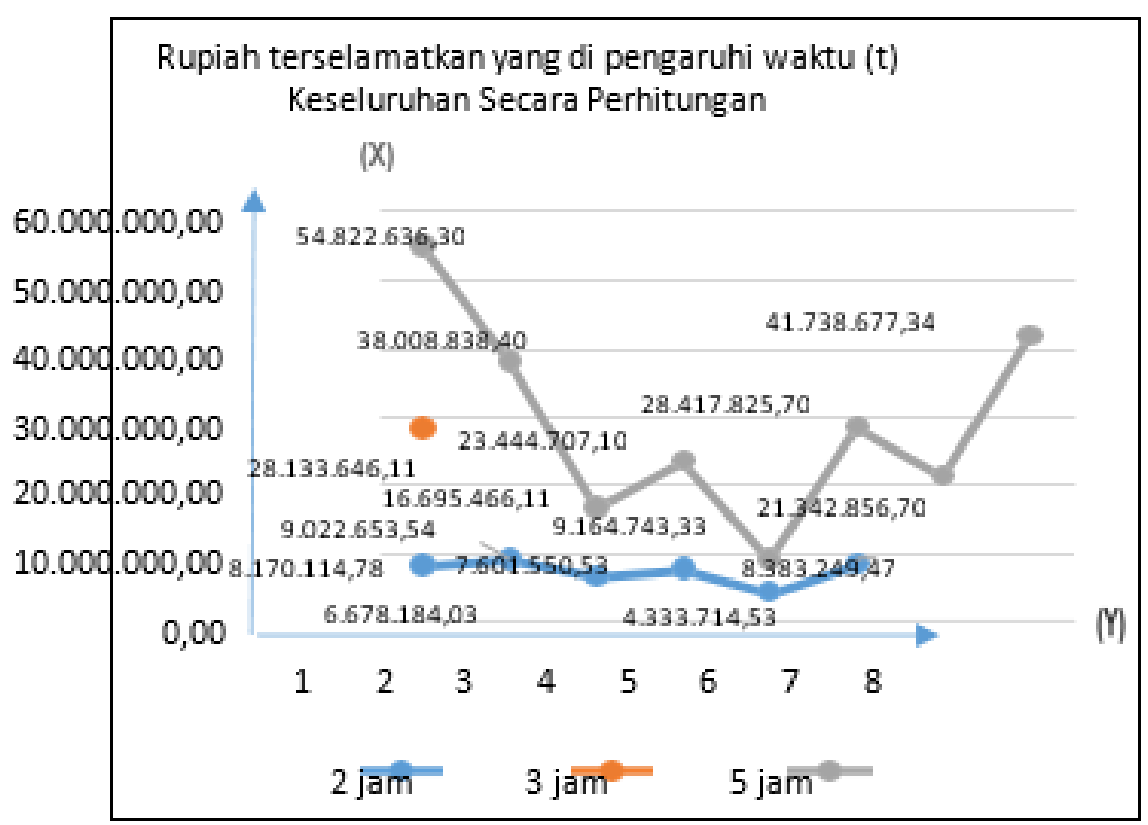

Gambar 12 : Grafik Rupiah terselamatkanKeseluruhan Secara perhitungan

Grafik diatas dimana grafik di atas menunjukan hubungan perkiraan rupiah terselamatkan terhadap arus dan lama pengerjaan PDKB. sumbu $\mathrm{X}$ menunjukan nilai rupiah terselamatkan, Sedangkan sumbu Y merepresentasikan lama waktu pengerjaan PDKB pada kurva diatas dapat dilihat bahwa, semakin lama pengerjaan semakin besar juga nilai rupiah yang terselamatkan.

\section{Perhitungan Arus beban penyulang}

Perhitungan Arus beban penyulang dapat dirumuskan dengan :

$$
\mathbf{I}=\frac{\mathrm{Plgn} \times \mathrm{P} \text { rata-rata }}{\mathrm{V} \times \sqrt{3} \mathrm{x} \operatorname{Cos} Q}
$$

Keterangan :

$$
\begin{array}{ll}
\mathrm{I} & =\text { Arus Beban }(\text { Ampere }) \\
\text { Plgn } & =\text { Jumlah Pelanggan } \\
\text { P Rata- rata } & =\text { Daya rata }- \text { rata }(\text { VA }) \\
\mathrm{V} & =\text { Tegangan }(\mathrm{V})
\end{array}
$$

$$
\begin{array}{ll}
\sqrt{3} & =3 \text { Fasa }(\text { R S T }) \\
\operatorname{Cos} Q & =0,85 \text { (Faktor Daya) }
\end{array}
$$

\section{Contoh Perhitungan}

$$
\begin{aligned}
I & =\frac{\text { Plgn } \times \text { P rata-rata }}{\mathrm{V} \times \sqrt{3} \times \operatorname{Cos} Q} \\
& =\frac{4.965 \times 450}{20 \mathrm{KV} \times \sqrt{ } 3 \times 0,85} \\
& =\frac{2234,25}{29,410}
\end{aligned}
$$

Maka untuk menghitung Energi yang terselamatkan, dapat menggunakan rumus :

\section{Energi (kWh) yang terselamatkan}

$=\sqrt{3} \times \overline{\mathrm{V}} \times \mathrm{I} \times \operatorname{Cos} \boldsymbol{Q} \times \mathrm{t}$

$$
1000
$$

\section{Contoh Perhitungan}

$=\sqrt{3} \times 20000 \times 75 \times 0,85 \times 2$ 1000 
$=$

Keterangan :

$$
\begin{array}{ll}
\mathrm{I} & =\text { Arus Beban (Ampere) } \\
\sqrt{3} & =1,73(\mathrm{R} \mathrm{S} \mathrm{T}) \\
\mathrm{V} & =\text { Tegangan }(\mathrm{V}) \\
\text { Cos } \boldsymbol{Q} & =0,85(\text { Faktor Daya) } \\
\mathrm{T} & =\text { Waktu Pekerjaan }
\end{array}
$$

Dari hasil tersebut didapatkan hasil Rupiah yang diselamatkan yang dapat digunakan dengan rumus :

Rpsafe $=$ Energi $(\mathrm{kWh})$ Terselamatkan $\mathrm{x}$

$$
\text { Rp (PerkWh) }
$$

Keterangan :

Rpsafe $=$ Rupiah terselamatkan

Rp $($ Per kWh $)=$ Total Rupiah Jual Unit

Total kWh Jual Unit

\section{Contoh Perhitungan}

Besar energy terselamatkanterhadap harga jual listrik PLN Jawa Barat Bandung bulan Juni 2020 sebesar Rp1206,40/kWh, maka didapat jumlah rupiah terselamatkan sebesar :

$$
\begin{aligned}
\text { Rpsafe } & =4416,72 \times 1206,40 \\
& =\operatorname{Rp} 5.328 .342,54
\end{aligned}
$$

\section{Analisa}

Setelah melakukan pengambilan data dan perhitungan ini maka ada beberapa hal yang dapat dianalisis, yaitu:

\section{Energi terselamatkan}

Energi terselamatkan adalah listrik energi yang masih dapat tersalurkan saat pekerjaan dilakukan tanpa pemadaman.

Dalam pemeliharaan PDKB mempunyai target nilaiEnergi Terselamatkan dan Rupiah Terselamatkan yang sudah di tetapkan tim PDKB, kita dapat membandingkan dari hasil pekerjaan yang di dapat dengan target yang sudah di tetapkan selama satu bulan dengan hasil pengukuran dan perhitungan. Dari pengerjaan tim PDKB selama satu bulan dapat mencapai target yang diinginkan, dengan $\mathrm{kWh}$ yang didapat sebesar 537,204.30, dengan keuntungan melebihi target $\mathrm{kWh} 175,043,1$, dari hasil pekerjaan PDKB yang dapat mencapai target ini bisa di sebabkan karena lama nya pekerjaan yang melebihi bobot yang sudah di tetapkan PDKB, oleh karena itu semakin lama pengerjaan PDKB maka semakin besar $\mathrm{kWh}$ dan rupiah yang diselamatkan hal ini bisa dilihat pada table hasil perhitungan di atas.

\section{KESIMPULAN}

Berdasarkan hasil Penelitian yang dilakukan oleh penulis bahwasanya ada beberapa hal yang dapat disimpulkan terkait pada penelitian ini, yaitu :

1. Dengan menggunakan Teknik PDKB, lebih menguntungkan pihak PLN dikarenakan listrik masih tersalurkan walaupun dalam pemeliharaan atau perbaikan tanpa ada nya pemadaman, sehingga adanya PDKB ini dapat menguntungkan PLN maupunkonsumen yang menggunakan listrik.

2. Selain itu, keuntungan yang didapat dengan menggunakan teknik PDKB berupa Energi terselamatkan dan Rupiah Terselamatkan.

3. Hasil yang didapat dengan 
menggunakan Pengukuran menunjukan bahwa Energi Terselamatkan yang didapatkan sebesar 510.260,43 KWh (Kilo Watt hour) dan Rupiah Terselamatkan sebesar 615.578.183,42 Rupiah. Sedangkan hasil yang didapat dengan menggunakan Perhitungan menunjukan bahwa hasil Energi Terselamatkan adalah sebesar 678.477,24 KWh (Kilo Watt hour) Rupiah Terselamatkan sekitar 835.435.301,46 Rupiah selama 1 bulan pada bulan Juni 2020.

4. Dapat disimpulkan dari perbandingan yang di dapat dengan menggunakan perhitungan lebih besar nilai keuntunganya dibandingkan dengan menggunakan pengukuran. Ini disebabkan karena adanya human error, perbedaan beban penyulang antara pengukuran dan perhitungan.

5. Kontribusi yang dapat dikembangkan atau disalurkan untuk PLN yaitu Energi terselamatkan sesuai dengan perhitungan, Arus dan juga Rupiah yang terselamatkan. Sehingga mendapatkan perbandingan dari hasil perhitungan dan pengujian di PLN.

\section{DAFTAR PUSTAKA}

[1]. SPLN 82-1, 1991, PDKB tentang Peraturan Umum.

[2]. Team PDKB.2005. Pedoman PDKB (Pedoman Umum Pemeliharaan Transmisi TT/TET dengan PDKB).PT. PLN (Persero) Penyaluran dan Pusat PengaturanBeban Jawa Bali.

[3]. SPLN 1985:59, Keandalan Sistem Tenaga Listrik.

[4]. SPLN 81-1, 1993, PDKB Tentang Jaringan Tegangan Menengah, Persyaratan Kerja, dan Lembaran Teknik Perkakas.

[5]. Vernandez, Brenda, 2013, Perhitungan KWH terselematkan pada $P D K B$ 